No difference in disease activity parameters between patients receiving the originator or biosimilars were noted, neither at baseline, during the course of treatment nor at last observation upon treatment (Figure 1). At the time of switching, $46(92 \%)$ had JADAS minimal disease activity (MDA) and $30(69 \%)$ were in JASDAS remission. At last observation, those numbers were comparable with 42 (86\%) with JADAS MDA and 28 (57\%) with JADAS remission.

In total, 45 adverse events (AE) were reported in 45 patients upon biosimilar treatment. 26 patients had 1, 12 patients had 2 and 6 patients reported 3 and 1 reported 4 events. Adverse event of special interest were Infection associated leukopenia $(n=1)$, COVID 19 infection $(n=1)$, Uveitis flare $(n=8)$, other disease deterioration (arthritis flare) $(n=20)$, injection site reaction $n=2$. A single serious AE was reported. A 16 year old female adolescent was admitted for unexpected CK elevation. In 10 patients, Adalimumab was discontinued, in 2 it was temporarily paused.

Conclusion: This article is the first attempt to present a large sample of data on JIA patients exposed to Adalimumab biosimilars. Since approval of Adalimumab-Biosimilars, limited experience from clinical practice is available. Biosimilars are used in a minority of patients and by a minority of centers although no difference in efficacy or safety was noted from our analysis.

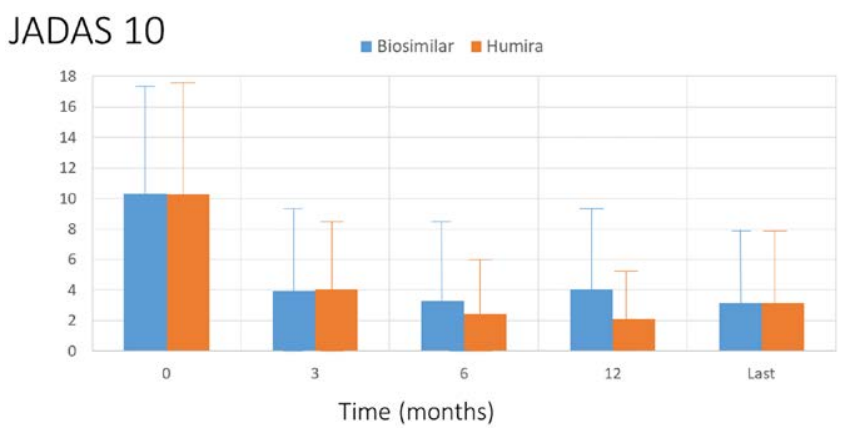

Disclosure of Interests: Gerd Horneff Speakers bureau: Novartis, MSD, Sobi, Grant/research support from: MSD, Roche, Frank Dressler: None declared, Michael Rühlmann: None declared, Tilmann Geikowski: None declared, Sonja Mrusek: None declared, Ariane Klein: None declared DOI: 10.1136/annrheumdis-2021-eular.1433

\section{POS1304 JUVENILE SYSTEMIC SCLEROSIS (JSSC) PATIENTS WITH OVERLAP CHARACTERISTICS DO NOT HAVE MILD DISEASE. RESULTS FROM THE JSSC INCEPTION COHORT. WWW.JUVENILE- SCLERODERMA.COM}

I. Foeldvari ${ }^{1}$, J. Klotsche ${ }^{2}$, O. Kasapcopur ${ }^{3}$, A. Adrovic ${ }^{3}$, K. Torok ${ }^{3}$, M. T. Terreri ${ }^{3}$, A. P. Sakamoto ${ }^{3}$, B. Feldman ${ }^{3}$, V. Stanevicha ${ }^{3}$, J. Anton ${ }^{3}$, F. R. Sztajnbok ${ }^{3}$, R. Khubchandani ${ }^{3}$, E. Alexeeva ${ }^{3}$, M. Katsikas ${ }^{3}$, S. Sawhney ${ }^{3}$, V. Smith ${ }^{3}$, S. Appenzeller ${ }^{3}$, T. Avcin ${ }^{3}$, M. Kostik ${ }^{3}$, T. Lehman ${ }^{3}$, E. Marrani ${ }^{3}$, D. Schonenberg ${ }^{3}$, W. A. Sifuentes-Giraldo ${ }^{3}$, N. Vasquez-Canizares ${ }^{3}$, M. Janarthanan ${ }^{3}$, M. Moll ${ }^{3}$, D. Nemcova ${ }^{3}$, A. Patwardhan ${ }^{3}$, M. J. Santos ${ }^{3}$, C. Battagliotti ${ }^{3}$, L. Berntson ${ }^{3}$, B. Bica ${ }^{3}$, J. Brunner ${ }^{3}$, R. Cimaz ${ }^{3}$, P. Costa Reis ${ }^{3}$, D. Eleftheriou ${ }^{3}$, L. Harel ${ }^{3}$, G. Horneff ${ }^{3}$, S. Johnson ${ }^{3}$, D. Kaiser ${ }^{3}$, T. Kallinich ${ }^{3}$, D. Lazarevic ${ }^{3}$, K. Minden ${ }^{2}$, S. Nielsen ${ }^{3}$, F. Nuruzzaman ${ }^{3}$, S. Opsahl Hetlevik ${ }^{3}$, Y. Uziel ${ }^{3}$, N. Helmus ${ }^{1}{ }^{1}$ Hamburg Centre for Pediatric and Adolescence Rheumatology, Schön Klinik Hamburg Eilbek, Hamburg, Germany; ${ }^{2}$ German Rheumatism Research Center, German Rheumatism Research Center, Berlin Germany; ${ }^{3}$ JSSC Collaborative Group, Hamburg Centre for Pediatric and Adolescence Rheumatology, Hamburg, Germany

Background: Juvenile systemic sclerosis (jSSc) is an orphan disease with a prevalence of around 3 in 1,000,000 children. It is known that in pediatric jSSc cohorts, there are a significant number of patients with overlap features, such as arthritis and myositis. However, the disease burden between those with and without overlap features in jSSc has not been defined.

Objectives: Compare the clinical phenotype between children with and without overlap features in the juvenile systemic scleroderma inception cohort (jSScC). Methods: A cross-sectional study was performed using baseline visit data. Demographic, organ system evaluation, autoantibody profile, treatment, and patient and physician reported outcome variables were extracted from jSScC. Comparison between patients with and without overlap features was performed using chi-square test and Mann Whitney U-test.

Results: At the time of data extraction, 175 jSSc patients were enrolled in the cohort, $81 \%$ were Caucasian and $81 \%$ female. Mean disease duration was 3.1 year $( \pm 2.7)$. Mean age at Raynaud's onset was 10 years $( \pm 3.8)$ and mean age of first non-Raynaud's was 10.2 years $( \pm 3.8)$. Overlap features occurred $17 \%$ $(n=30)$ of the cohort, $12.5 \%$ in the diffuse cutaneous (dc) jSSc and in $30 \%$ in the limited cutaneous (Ic) jSSc. Significant differences in clinical characteristics were found between those patients with compared to without overlap character istics. Patients with overlap features presented more frequently with Gottron papules $(p=0.007)$, swollen joints $(p=0.019)$, muscle weakness $(p=0.003)$, and lung involvement documented by decreased DLCO $<80 \%(p=0.06)$ and/or abnormal high resolution computed tomography $(p=0.049)$. Anti-PM/Scl autoantibodies were also more common in this group $(p=0.001)$. Significantly more patients without overlap features had Raynaud's $(p=0.006)$. Physician Global Assessment of disease activity was significantly higher in patients with overlap features (41 vs 34; $p=0.041$ ). (Table 1.)

Table 1. Demographic and clinical characteristics of jSSc patients with and without overlap features.

\begin{tabular}{|c|c|c|c|c|}
\hline & $\begin{array}{l}\text { Whole Cohort } \\
\mathrm{N}=175\end{array}$ & $\begin{array}{l}\text { Patients without } \\
\text { overlap } \\
\mathrm{N}=145\end{array}$ & $\begin{array}{l}\text { Patients with } \\
\text { overlap } \\
\mathrm{N}=30\end{array}$ & $\begin{array}{l}P \\
\text { value }\end{array}$ \\
\hline Female to Male Ratio & $\begin{array}{l}4.3: 1 \\
(142 / 33)\end{array}$ & $\begin{array}{l}4: 1 \\
(116 / 29)\end{array}$ & $\begin{array}{l}6.5: 1 \\
(26 / 4)\end{array}$ & 0.395 \\
\hline \multicolumn{5}{|l|}{ Cutaneous subtype } \\
\hline Diffuse subtype $(\mathrm{N})$ & $73 \%(128)$ & 112 & 16 & \\
\hline Limited subtype $(\mathrm{N})$ & $27 \%(47)$ & 33 & 17 & \\
\hline $\begin{array}{l}\text { Mean disease duration } \\
\text { (years) }\end{array}$ & $3.1( \pm 2.7)$ & $3.2( \pm 2.8)$ & $3.1( \pm 2.2)$ & 0.291 \\
\hline Mean age of onset of & $10.0( \pm 3.8)$ & $10.0( \pm 3.8)$ & $10.0( \pm 3.7)$ & 0.931 \\
\hline $\begin{array}{l}\text { Raynaud's (years) } \\
\text { Mean age of onset of } \\
\text { non-Raynaud's (vears) }\end{array}$ & $\begin{array}{l}17 \text { non-Raynaud } \\
10.2( \pm 3.8)\end{array}$ & $\begin{array}{l}10 \text { non-Raynaud } \\
10.2( \pm 3.9)\end{array}$ & $\begin{array}{l}7 \text { non-Raynaud } \\
9.8( \pm 3.7)\end{array}$ & \\
\hline Disease modifying drugs $(\mathrm{N})$ & $88 \%(154)$ & $89 \%(129)$ & $83 \%(25)$ & 0.388 \\
\hline Raynaud's phenomenon & $90 \%(158)$ & $93 \%(135)$ & $77 \%(23)$ & 0.006 \\
\hline Anti-PMScl & $18 \%(12 / 68)$ & $9 \%(5 / 53)$ & $47 \%(7 / 15)$ & 0.001 \\
\hline Gottron Papules (N) & $27 \%(46 / 171)$ & $23 \%(33 / 144)$ & $48 \%(13 / 27)$ & 0.007 \\
\hline DLCO $<80 \%(N)$ & $44 \%(39 / 88)$ & $39 \%(28 / 71)$ & $65 \%(11 / 17)$ & 0.06 \\
\hline $\begin{array}{l}\text { Abnormal findings in HRCT } \\
(\mathrm{N})\end{array}$ & $44 \%(59 / 133)$ & $40 \%(43 / 107)$ & $62 \%(16 / 26)$ & 0.049 \\
\hline $\begin{array}{l}\text { Proportion of patients with } \\
\text { swollen joints }\end{array}$ & $18 \%(32)$ & $14 \%(21)$ & $37 \%(11)$ & 0.019 \\
\hline Muscle Weakness $(\mathrm{N})$ & $21 \%(31 / 149)$ & $16 \%(20 / 123)$ & $42 \%(11 / 26)$ & 0.003 \\
\hline $\begin{array}{l}\text { Physician global disease } \\
\text { activity }(0-100) \text { min -max }\end{array}$ & $35(0-90) n=141$ & $34(0-90) n=114$ & $41(0-80) n=27$ & 0.041 \\
\hline
\end{tabular}

Conclusion: Results from this large international cohort of jSSc patients demonstrate significant differences between patients with and without overlap features. Patients with overlap have significantly more interstitial lung disease and more physician rated disease activity and should not be considered to have more "mild disease".

Supported by the "Joachim Herz Stiftung"

Disclosure of Interests: None declared

DOI: 10.1136/annrheumdis-2021-eular.1613

\begin{tabular}{l|l}
\hline POS1305 & TREATMENT RESPONSE TO TUMOR NECROSIS \\
& FACTOR INHIBITORS IN ADULTS WITH JUVENILE \\
& IDIOPATHIC ARTHRITIS: DATA FROM THE NOR- \\
& DMARD STUDY
\end{tabular}

I. Bardan ${ }^{1}$, K. M. Fagerli², J. Sexton ${ }^{2}$, G. Bakland ${ }^{3}$, P. Mielnik ${ }^{4}$, L. M. Paucar Loli $^{5}$, T. K. Kvien ${ }^{1,2}$, E. Kristianslund ${ }^{2}$, A. B. Aga ${ }^{2,6}$. ${ }^{1}$ University of Oslo, Faculty of Medicine, Oslo, Norway; ${ }^{2}$ Diakonhjemmet Hospital, Division of Rheumatology and Research, Oslo, Norway; ${ }^{3}$ University Hospital Northern Norway, Department of Rheumatology, Oslo, Norway; ${ }^{4} \mathrm{Helse}$ Førde, Section for Rheumatology, Department for Neurology, Rheumatology and Physical Medicine, Førde, Norway; ${ }^{5}$ Lillehammer Hospital for Rheumatic Diseases, Department of Rheumatology, Lillehammer, Norway; ${ }^{6}$ Oslo University Hospital, Department of Rheumatology, Oslo, Norway

Background: Juvenile idiopathic arthritis (JIA) can cause considerable pain and disability in childhood and adulthood. Studies exploring the efficacy of medications in adult JIA patients are limited, although tumor necrosis factor inhibitors (TNFi) have been increasingly used in this patient group.

Objectives: To explore the efficacy of TNFi \pm comedication on disease activity in adult JIA patients, compared to a weighted rheumatoid arthritis (RA) cohort.

Methods: Data from NOR-DMARD, a longitudinal observational study including patients $>18$ years starting or switching DMARD treatment, was used [1] Patients with a clinical JIA diagnosis, or patients with other inflammatory joint diseases diagnosed before 16 years were identified from the study population. RA patients were included for comparative purposes.

Disease activity measurements and remission rates among patients starting treatment with $\mathrm{TNFi} \pm$ comedication were collected at baseline, 3 and 6 months 
Changes in disease activity and absolute remission rates after 3 and 6 months were calculated. Remission rates and change in disease activity from baseline were compared between JIA patients and a weighted RA cohort with weights based on age and gender, using linear and logistic regression for continuous and categorical variables, respectively.

Results: 281 JIA patients $(68.9 \%$ female, mean (SD) age 32.1 (11.1) years, mean (SD) diagnosis duration 23.5 (12.2) years) and 1374 RA patients $(71.6 \%$ female, mean (SD) age 52.7 (14.5) years, mean (SD) diagnosis duration 9.5 (10.0) years) were included in the analyses. Age, gender distribution and disease duration differed significantly between cohorts.

Both groups had a significant improvement across all disease activity measures after 3 months (Table 1), which was maintained after 6 months across all measures except MHAQ. The RA group had a significantly greater 3- and 6-month improvement in SJC28. Both groups had an overall 6-month increase in absolute remission rates. The JIA group had a significantly higher 3-month DAS28 remission rate (Figure 1). This difference was not significant after 6 months, as remission rates from 3 to 6 months in the JIA group declined across all measures.

Table 1.

\begin{tabular}{|c|c|c|c|c|c|c|c|c|c|}
\hline & \multicolumn{3}{|c|}{ Baseline } & \multicolumn{3}{|c|}{ Change to 3 months } & \multicolumn{3}{|c|}{ Change to 6 months } \\
\hline & $\mathrm{JIA}^{*}$ & $\mathbf{R A}^{*}$ & Diff. $\S$ & JIA* & $\mathbf{R A}^{*}$ & Diff. $^{\S}$ & JIA* & $\mathbf{R A}^{*}$ & Diff. ${ }^{\S}$ \\
\hline $\begin{array}{l}\mathrm{ESR}, \\
\mathrm{mm} / \mathrm{h}\end{array}$ & $\begin{array}{l}18.7 \\
(18.9)\end{array}$ & $\begin{array}{l}25.5 \\
(22.0)\end{array}$ & $\begin{array}{c}1.3(-2.3 \text { to } \\
4.9)\end{array}$ & $\begin{array}{l}-7.4 \\
(15.8)\end{array}$ & $\begin{array}{l}-7.6 \\
(16.6)\end{array}$ & $\begin{array}{r}-0.3(-4.4 \\
\text { to } 3.8)\end{array}$ & $\begin{array}{l}-7.4 \\
(16.8)\end{array}$ & $\begin{array}{l}-8.5 \\
(18.2)\end{array}$ & $\begin{array}{r}0.0(-5.7 \\
\text { to } 5.7)\end{array}$ \\
\hline SJC28 & $\begin{array}{l}2.5 \\
(3.6)\end{array}$ & $\begin{array}{l}5.5 \\
(5.4)\end{array}$ & $\begin{array}{c}1.6 \text { (1.3 to } \\
2.0)\end{array}$ & $\begin{array}{l}-1.4 \\
(3.4)\end{array}$ & $\begin{array}{l}-3.1 \\
(4.7)\end{array}$ & $\begin{array}{c}-1.0(-1.7 \text { to } \\
-0.3)\end{array}$ & $\begin{array}{l}-1.6 \\
(3.2)\end{array}$ & $\begin{array}{l}-3.5 \\
(5.1)\end{array}$ & $\begin{array}{c}-1.0(-1.9 \\
\text { to } \\
-0.1)\end{array}$ \\
\hline TJC 28 & $\begin{array}{l}4.0 \\
(5.6)\end{array}$ & $\begin{array}{l}6.6 \\
(6.4)\end{array}$ & $\begin{array}{c}1.3(0.4 \text { to } \\
2.3)\end{array}$ & $\begin{array}{l}-1.8 \\
(3.9)\end{array}$ & $\begin{array}{l}-3.1 \\
(5.9)\end{array}$ & $\begin{array}{c}-0.6(-1.4 \text { to } \\
0.2)\end{array}$ & $\begin{array}{l}0-1.8 \\
(3.9)\end{array}$ & $\begin{array}{l}-3.9 \\
(6.2)\end{array}$ & $\begin{array}{r}-1.0(-2.0 \\
\text { to } 0.1)\end{array}$ \\
\hline DAS28 & $3.6(1.4)$ & $4.5(1.6$ & $\begin{array}{c}0.3(0.1 \text { to } \\
0.6)\end{array}$ & $\begin{array}{l}-1.2 \\
(1.3)\end{array}$ & $\begin{array}{l}-1.2 \\
(1.4)\end{array}$ & $\begin{array}{r}-0.0(-0.3 \\
\text { to } 0.3)\end{array}$ & $\begin{array}{l}-1.2 \\
(1.3)\end{array}$ & $\begin{array}{l}-1.5 \\
(1.4)\end{array}$ & $\begin{array}{r}-0.2(-0.6 \\
\text { to } 0.2)\end{array}$ \\
\hline SDAI & $\begin{array}{l}16.8 \\
(10.6)\end{array}$ & $\begin{array}{l}23.1 \\
(14.3)\end{array}$ & $\begin{array}{c}2.4 \text { (0.3 to } \\
4.5)\end{array}$ & $\begin{array}{l}-7.7 \\
(9.9)\end{array}$ & $\begin{array}{l}-10.9 \\
(12.7)\end{array}$ & $\begin{array}{r}-2.0(-4.2 \\
\text { to } 0.2)\end{array}$ & $\begin{array}{l}-7.9 \\
(8.6)\end{array}$ & $\begin{array}{l}-13.2 \\
(13.6)\end{array}$ & $\begin{array}{r}-2.8(-5.8 \\
\text { to } 0.2)\end{array}$ \\
\hline PGA & $\begin{array}{l}51.4 \\
(26.3)\end{array}$ & $\begin{array}{l}49.9 \\
(25.5)\end{array}$ & $\begin{array}{r}-4.0(-8.5 \\
\text { to } 0.5)\end{array}$ & $\begin{array}{l}-20.6 \\
(26.7)\end{array}$ & $\begin{array}{l}-17.0 \\
(26.7)\end{array}$ & $\begin{array}{c}2.7(-2.2 \text { to } \\
7.6)\end{array}$ & $\begin{array}{l}-21.6 \\
(25.3)\end{array}$ & $\begin{array}{l}-19.1 \\
(28.7)\end{array}$ & $\begin{array}{r}3.4(-3.0 \\
\text { to } 9.8)\end{array}$ \\
\hline MHAQ & $\begin{array}{l}0.6 \\
(0.5)\end{array}$ & $\begin{array}{l}0.7 \\
(0.5)\end{array}$ & $\begin{array}{c}0.0(-0.1 \text { to } \\
0.1)\end{array}$ & $\begin{array}{l}-0.24 \\
(0.42)\end{array}$ & $\begin{array}{l}-0.22 \\
(0.42)\end{array}$ & $\begin{array}{c}0.0(-0.1 \text { to } \\
0.1)\end{array}$ & $\begin{array}{l}-0.23 \\
(0.40)\end{array}$ & $\begin{array}{l}-0.25 \\
(0.45)\end{array}$ & $\begin{array}{r}0.0(-0.1 \\
\text { to } 0.1)\end{array}$ \\
\hline
\end{tabular}

${ }^{\star}$ Mean $(\mathrm{SD})^{\S}$ Weighted group difference, RA coefficient (95\% confidence interval)

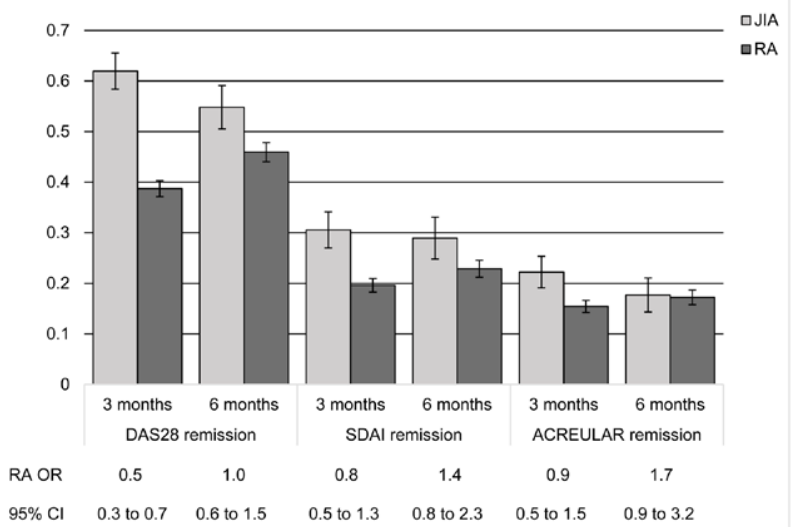

Figure 1. Mean 3- and 6-month remission rates with error bars (SE)

Conclusion: TNFi was equally effective in reducing disease activity in the JIA and RA cohort after 3 and 6 months, and in inducing remission after 6 months. Absolute remission rates in the JIA group declined from 3 to 6 months across all measures, and studies with longer duration are needed to explore the long-term efficacy of TNFi in the patient groups.

REFERENCES:

[1] Kvien, T.K., et al., A Norwegian DMARD register: prescriptions of DMARDs and biological agents to patients with inflammatory rheumatic diseases. Clin Exp Rheumatol, 2005. 23(5 Suppl 39): p. S188-94.

Disclosure of Interests: Imane Bardan: None declared, Karen Minde Fagerli: None declared, Joe Sexton: None declared, Gunnstein Bakland Speakers bureau: Abbvie, Consultant of: UCB, Pfizer, Novartis, Pawel Mielnik: None declared, Liz Marina Paucar Loli: None declared, Tore K. Kvien Speakers bureau: Fees for speaking: Amgen, Celltrion, Egis, Evapharma, Ewopharma, Hikma, Oktal, Sandoz, Sanofi, Consultant of: Fees for consulting: AbbVie, Amgen, Biogen, Celltrion, Eli Lilly, Gliead, Mylan, Novartis, Pfizer, Sandoz, Sanofi, Grant/ research support from: Received research funding to Diakonhjemmet Hospital from Abbvie, Amgen, BMS, MSD, Pfizer and UCB, Eirik kristianslund: None declared, Anna-Birgitte Aga Grant/research support from: Dr. Aga reports personal fees from Abbvie, Eli Lilly, Novartis and Pfizer, outside the submitted work DOI: 10.1136/annrheumdis-2021-eular.1708

\section{POS1306 TREATMENT STRATEGIES IN CHRONIC RECURRENT MULTIFOCAL OSTEOMYELITIS (CMRO) OR CHRONIC NON-BACTERIAL OSTEOMYELITIS (CNO): SYSTEMATIC REVIEW AND META-ANALYSIS}

R. Dos-Santos ${ }^{1}$, C. Gomez-Vieites ${ }^{1}$, D. Fernández Fernández ${ }^{1}$, I. González Fernández ${ }^{1}$, A. Souto Vilas ${ }^{1}$, E. Perez-Pampín ${ }^{1}$, A. Mera Varela ${ }^{1} .{ }^{1}$ Clinical University Hospital in Santiago de Compostela, Rheumatology Department, Santiago de Compostela, Spain

Background: Glucocorticoids (GC), bisphosphonates (BP), non-steroida anti-inflammatory drugs (NSAID) and classical synthetic or biological disease-modifying antirheumatic drugs (cs/bDMARD) have been employed in the treatment of chronic recurrent multifocal osteomyelitis (CRMO) or chronic non-bacterial osteomyelitis (CNO). ${ }^{1,2}$ This one is a rare bone childhood illness and none treatment guidelines have been carried out till present. ${ }^{3}$

Objectives: To asses which treatment schedule employed in CRMO had the best response rates and try to expose a treatment recommendation.

Methods: A systematic literature review was made using Medline, Embase, Cochrane library and the Web of Science databases. The search strategy focused on synonyms of CRMO. A prevalence meta-analysis was performed to evaluate each treatment response. Stata 15.1 was used to perform statistical analysis.

Results: The search identified 1883 articles, of which 43 were finally selected. Complete response rate reached with NSAIDs was acceptable $[50 \%$ (Cl95\% 40-60)]. Lower response rates were reached by GC treatment [44\% (Cl95\% 25-63)] or csDMARD [38\% (CI95\% 28-48)]. The best complete response rates were reached by bDMARD and BP treatments [69\% (CI95\% 56-82) and $73 \%$ (Cl95\% 62-84), respectively].

Conclusion: This review and meta-analysis supports, taking into account its remission rates and its risk-benefit profile, NSAIDs as potential first-line agents in CRMO treatment. bDMARD and BP have reached the higher remission rates, turning into helpful treatment alternatives. There is not any treatment guidelines driving CRMO patients, but this analysis could help to select a suitable agent for each patient. Decision-making should be individualized.

\section{REFERENCES:}

[1] Wipff J, Costantino F, Lemelle I, et al. A large national cohort of French patients with chronic recurrent multifocal osteitis. Arthritis \& Rheumatol. 2014;67(4):1128-1137.

[2] Zhao Y, Wu EY, Oliver M S, et al. Consensus treatment plans for chronic nonbacterial osteomielitis refractory to nonsteroideal anti-inflammatory drugs and/or with active spinal lesions. Arthritis Care Res. 2018;70(8):1228-1237.

[3] Menashe SJ, Aboughalia $\mathrm{H}$, Zhao $\mathrm{Y}$, et al. The many faces of pediatric chronic recurrent multifocal osteomyelitis (CRMO): a practical location- and case-based approach to differenciate CRMO from its mimics. J Magn Reson Imaging. 2020;e27299.

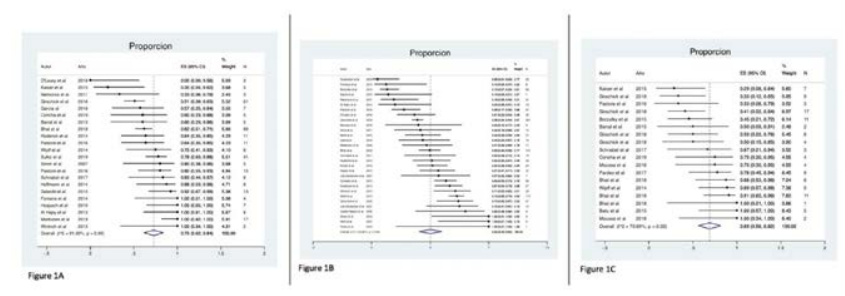

Disclosure of Interests: None declared DOI: 10.1136/annrheumdis-2021-eular.1890

\section{POS1307 ULTRASOUND-DETECTED TENOSYNOVITIS IN ANKLES WITH CLINICALLY ACTIVE DISEASE OF CHILDREN WITH NEW-ONSET JUVENILE IDIOPATHIC ARTHRITIS DOES NOT AFFECT THE CHANCE TO ACHIEVE DISEASE REMISSION}

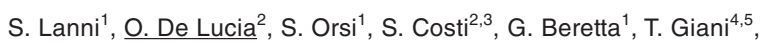
G. Filocamo ${ }^{1}$, C. V. Agostoni ${ }^{1,3}$, R. Cimaz ${ }^{3,6}$ on behalf of PRAGMA (Pediatric Rheumatology Associated Group of the Milan Area). ${ }^{1}$ Fondazione IRCCS Ca' Granda Ospedale Maggiore Policlinico di Milano, Milano, Italy, Paediatrics, Milano, Italy; ${ }^{2}$ Clinical Rheumatology Unit, ASST Centro Traumatologico Ortopedico G. Pini-CTO, Milano, Italy, Department of Rheumatology and Medical Sciences, Milano, Italy; ${ }^{3}$ University of Milano, 